\title{
Preparation and Utilization of Biogas Produced from Wastes in Slovakia
}

\author{
Peter Horbaj*, Peter Lukáč, Marián Lázár, Marta Lengyelová \\ Technical university of Košice, Faculty of Mechanical Engineering, Department of Power Engineering, Vysokoškolská 4, 04200 Košice, \\ Slovak Republik
}

\section{BIOGRAPHICAL NOTES}

prof. Ing. Peter Horbaj, CSc., is a professor at Department of Power Engineering, Faculty of Mechanical Engineering, Technical University of Košice. He is an author and coauthor of 7 textbooks, co-author of 1 patent and an author/co-author of 305 papers published in various local and international journals. He has presented results of his work on various international conferences. His research and project assignments focus on energy utilization of waste treatment, impulse burners, biogas stations, utilization of wood chips. He has been awarded several prizes.

Ing. Peter Lukáč, PhD., is a graduate of Thermal Power Engineering from Faculty of Metallurgy, Technical University of Košice. He currently works as a senior assistant professor at Department of Power Engineering, Faculty of Mechanical Engineering of TU of Košice. He takes part in solving research assignments, grants and projects at the department and the university. His research interest includes heat supply, compressors, pumps, combustion devices, cooling equipment and heat pumps. He is an author of over 50 original manuscripts published in local and international journals; conference papers and 4 university textbooks. He is a member of the Editorial Board of Gas-WaterHeating-Air-conditioning Journal.

Ing. Marián Lázár, PhD., is a scientific researcher at Department of Power Engineering, Faculty of Mechanical Engineering, Technical University of Košice. The main area of his work is focused on high temperature gasification and melting wastes.

Ing. Marta Lengyelová, is a PhD student at Department of Power Engineering, Faculty of Mechanical Engineering, Technical University of Košice. The main area of her work is focused on high temperature gasification and melting wastes.

\section{KEY WORDS}

Biomass, bio fuels, biogas, waste, utilization.

\section{ABSTRACT}

In the paper, the authors present actual situation in preparation of bio fuels from biomass in conditions of Slovakia and also some examples of utilization of produced bio fuel. There is short description of bio fuel produced from agricultural waste, from wood and from sewage treatment plant. These 3 ways are most common in our conditions.

\section{Introduction}

Energy, which we use today (heat, electricity, fuel for motor vehicles), has its origin mostly in the fossil fuels and resources of these fuels are limited. These fuels are lying under Earth's surface, where they were accrued from the primeval plants and animal decomposition over last stillion years. Although the fossil fuels are still generating in affect of the natural power (heat and pressure), their current usage multi exceed their 
production which means that we are running out of fossil fuels. That's the reason why fossil fuels are considered as not renewable [1]. Because our usage of energy is growing, we have to find another energy sources which could produce heat, electricity or whatever without using fossil fuels. One way could be bio fuels production from utilization of waste which is everywhere.

\section{Situation of utilization of wastes in Slovakia}

In Figure 1 we can see map of Slovakia and places where waste is commonly utilized for production of bio fuels and lately used for example in co-generation units. We can also see that main alternative energy source is wood. It is because our country is from $42 \%$ covered by forest. But large places covered by forest are protected by law so we are not allowed to do anything with this wood [2].

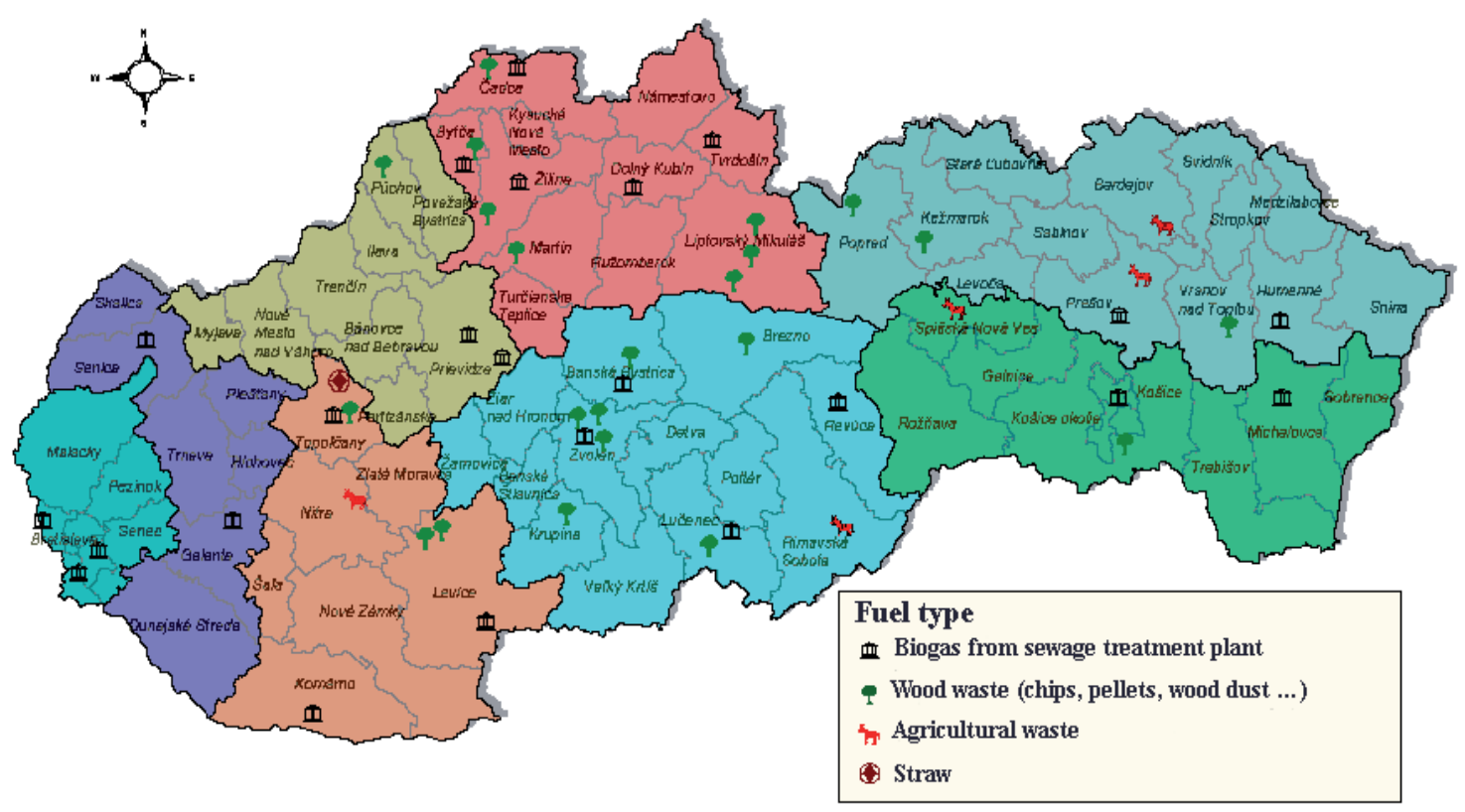

Fig. 1: Fuel types used as an alternative energy sources in Slovakia.

Another extensive energy sources for producing bio fuels are sewage treatment plants. Biogas which is produced by these plants is mainly used in co-generation units for producing electricity which is lately delivered to electrical power network. Electrical industry must buy all produced electricity for prices which are valid. These prices are valid just for one year and every year we have new prices. This brings doubts and unsafeness to potential investors who want to start business in this area or who already do business in alternative energy sources.

Very small amount of agricultural waste is used in present for producing bio fuels even if we were very good in agriculture at the end of 80's. But because many collective farms were closed, damaged and not used for years from there "golden years", usage of this energy source is limited even if potential is/was great.

\section{Biogas production}

In conditions of Slovakia is biogas produced from 2 main sources:

\section{- agricultural waste,}

\section{- sewage treatment plant.}

Simple diagram of producing biogas is in Figure 3 and Figure 4 short description of way for biogas production is as follows:

Agricultural waste which could be straw, excrements, silage is given to fermenter where is processed by microorganisms for several days. There must be correct temperature for best utilization of microorganisms and waste. Product of fermentation is biogas, dry matter and liquid manure. Dry matter and liquid manure can be used as ecological fertilizer because is without odor and pathogens. Produced biogas is used in co-generation unit for producing electricity, heat or cold or steam. Another possibility how to produce biogas is sewage treatment plant. Technology is slightly differ- 
ent but products are the same [2].

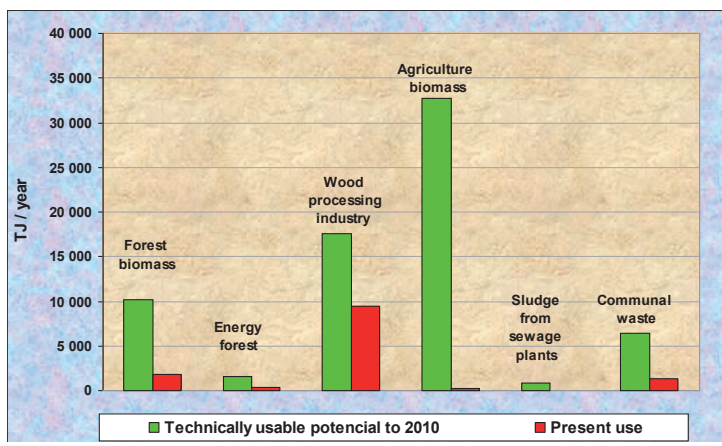

Fig. 2: Potential and present use of different alternative energy sources.

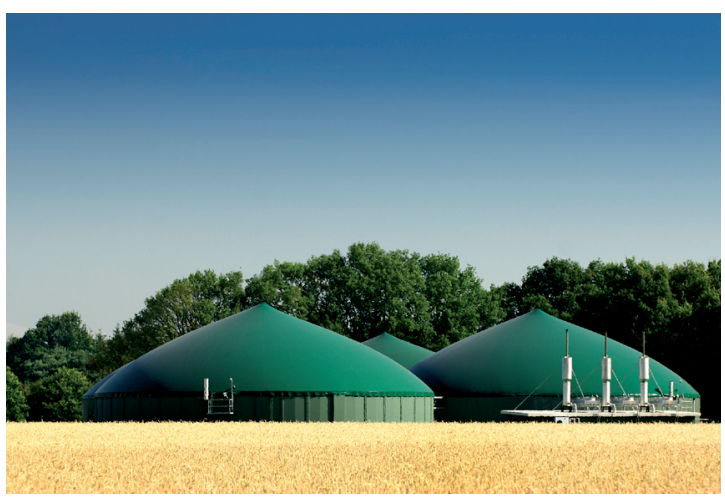

Fig. 3: View of the biogas plant.

Potential of agricultural biomass and waste is shown in Table 1 and Table 2.

Biogas from sewage treatment plant has great potential not only in Slovakia but also in other countries which do not use these plants as an en-

Table 1: Potential of agricultural biomass as an energy source

\begin{tabular}{|l|l|l|}
\hline Agriculture biomass & Usable potencial (t/year) & Energetic value (TJ/year) \\
\hline Grain straw & 272700 & 3861,00 \\
\hline Colza and sunflower straw & 161300 & 2223,30 \\
\hline Waste from fruit- tree gardens and from vineyards & 50400 & 528,60 \\
\hline Biooil-fuel & 5500 & 214,50 \\
\hline
\end{tabular}

Table 2: Potential of agricultural waste as an energy source.

\begin{tabular}{|c|c|c|c|c|c|}
\hline $\begin{array}{l}\text { Animal excrements } \\
\text { (unit) }\end{array}$ & $\begin{array}{l}\text { Dry matter of } \\
\text { excrements } \\
\text { (kg/day) }\end{array}$ & $\begin{array}{l}\text { Total amount } \\
\text { excrements } \\
\text { (kg/day) }\end{array}$ & $\begin{array}{l}\text { Capacity of biogas } \\
\text { ( } \mathrm{m}^{3} / \text { year) }\end{array}$ & $\begin{array}{l}\text { Electricity } \\
\text { (kW/year/1unit) }\end{array}$ & $\begin{array}{l}\text { Total amount of } \\
\text { farm animal } \\
\text { (ths.) }\end{array}$ \\
\hline Livestock & 13,75 & 140 & 1497 & 6110 & 665 \\
\hline Swine & 3,6 & 54 & 420 & 895 & 1562 \\
\hline Poultry & 0,076 & 0,267 & 6 & 53,8 & 10705 \\
\hline
\end{tabular}

Fig. 4: Simple diagram for biogas production [1].

ergy source. In Slovakia we have around 350 treatment plants all over the country. Annual capacity of produced sewage gas is about $31 \mathrm{mil}$. $\mathrm{m} 3$ what and about $386 \mathrm{TJ} /$ year of heat. Another electricity and heat we could earn from pyrolysis of sewage sludge because sewage sludge cannot be used as a fertilizer any more. Problem of sewage sludge pyrolysis could be high amount of heavy metals but this is only in plants which are near heavy industry.

Biodegradation of organic matter under anaerobic conditions is a process known as anaerobic fermentation or even methane fermentation. Metabolism of methane's bacteria, which occurs when bacteria break down organic matter. Process has four basic phases:

1. hydrolysis - hydrolysis microorganisms break down organic macromolecular substances into smaller molecules, where further reaction occurs,

2. acidogen phase - hydrolysis products are digested into simpler substances (acids, alcohols, $\mathrm{CO}_{2}, \mathrm{H}_{2}$ ),

3. aceton phase - formation of acetic acid, $\mathrm{CO}_{2}$ and $\mathrm{H}_{2}$, gives as potentially $60 \mathrm{GWh} /$ year of electricity 
4. methanogenic phase - the formation of methane from organic acids, a mixture of $\mathrm{CO}_{2}$ and $\mathrm{H}_{2}$.

\section{Hydrolysis}

$\left(\mathrm{C}_{6} \mathrm{H}_{12} \mathrm{O}_{6}\right)_{n}+n \mathrm{H}_{2} \mathrm{O} \longrightarrow n \mathrm{C}_{6} \mathrm{H}_{12} \mathrm{O}_{6}$

\section{Acidogen phase}

$\mathrm{C}_{6} \mathrm{H}_{12} \mathrm{O}_{6} \longrightarrow \mathrm{C}_{4} \mathrm{H}_{8} \mathrm{O}_{2}+2 \mathrm{CO}_{2}+2 \mathrm{H}_{2}$

Acetogen phase

$\mathrm{C}_{4} \mathrm{H}_{8} \mathrm{O}_{2}+2 \mathrm{H}_{2} \mathrm{O} \longrightarrow 2 \mathrm{C}_{2} \mathrm{H}_{4} \mathrm{O}_{2}+2 \mathrm{H}_{2}$

\section{Methanogenic phase}

$\mathrm{CO}_{2}+4 \mathrm{H}_{2} \longrightarrow \mathrm{CH}_{4}+2 \mathrm{H}_{2} \mathrm{O}$

\section{Methanogenic phase}

$\mathrm{C}_{2} \mathrm{H}_{4} \mathrm{O}_{2} \longrightarrow \mathrm{CH}_{4}+\mathrm{CO}_{2}$

During the formation of methane may occur more complex reactions:

$$
\begin{aligned}
& \mathrm{CH}_{3} \mathrm{COOH} \rightarrow \mathrm{CH}_{4}+\mathrm{CO}_{2}(70 \%) \\
& 4 \mathrm{HCOOH} \rightarrow \mathrm{CH}_{4}+3 \mathrm{CO}_{2}+2 \mathrm{H}_{2} \mathrm{O} \\
& 4 \mathrm{CH}_{3} \mathrm{OH} \rightarrow 3 \mathrm{CH}_{4}+\mathrm{CO}_{2}+2 \mathrm{H}_{2} \mathrm{O}
\end{aligned}
$$

\section{Trimethylamine}

$4\left(\mathrm{CH}_{3}\right)_{3} \mathrm{~N}+6 \mathrm{H}_{2} \mathrm{O} \rightarrow 9 \mathrm{CH}_{4}+3 \mathrm{CO}_{2}+4 \mathrm{NH}_{3}(9)$

\section{Dimethylamine}

$2\left(\mathrm{CH}_{3}\right)_{2} \mathrm{HN}+2 \mathrm{H}_{2} \mathrm{O} \rightarrow 3 \mathrm{CH}_{4}+\mathrm{CO}_{2}+2 \mathrm{NH}_{3}(10)$

\section{Monomethylamine}

$4 \mathrm{CH}_{3} \mathrm{NH}_{2}+2 \mathrm{H}_{2} \mathrm{O} \rightarrow 3 \mathrm{CH}_{4}+\mathrm{CO}_{2}+4 \mathrm{NH}_{3}(11)$

Biogas yield from known starting raw materials in the selected biogas plant in Eastern Slovakia:

$\begin{array}{ll}\text { - manure } & 35 \mathrm{~m}^{3} / \mathrm{t}, \\ \text { - suds } & 25 \mathrm{~m}^{3} / \mathrm{t}, \\ \text { - corn silage } & 200 \mathrm{~m}^{3} / \mathrm{t}, \\ \text { - grass silage } & 170 \mathrm{~m}^{3} / \mathrm{t}\end{array}$

The estimated amount of gas that is produced by decay of different materials is shown in the following table.

Per year can be produced from raw materials 937 $597 \mathrm{~m}^{3}$ of biogas.

From $1 \mathrm{~m}^{3}$ of biogas obtained:

$-1,7$ to 2,2 kWhe electricity

$-2,2$ to 4,0 kWh thermal energy

The average methane content in the produced
Table 3: The total amount of biogas per year.

\begin{tabular}{|l|l|}
\hline Raw material & Amount of biogas $\left.\mathbf{V}_{\mathbf{B}} \mathbf{( m}^{\mathbf{3}}\right)$ \\
\hline Manure & 129997,50 \\
\hline Suds & 41849,50 \\
\hline Corn silage & 600000 \\
\hline Grass silage & 165750 \\
\hline Total & 937597 \\
\hline
\end{tabular}

Table 4: The total amount of energy.

\begin{tabular}{|l|l|l|l|l|}
\hline \multicolumn{3}{|c}{ Electrical We } & Thermal Wt \\
\hline Energy & $\min$ & $\max$ & $\min$ & $\max$ \\
\hline (kWh/year) & 1593914,9 & 2062713,4 & 2062713,4 & 3750388 \\
\hline (kWh/day) & 4427,5 & 5729,7 & 5729,7 & 10417,7 \\
\hline
\end{tabular}

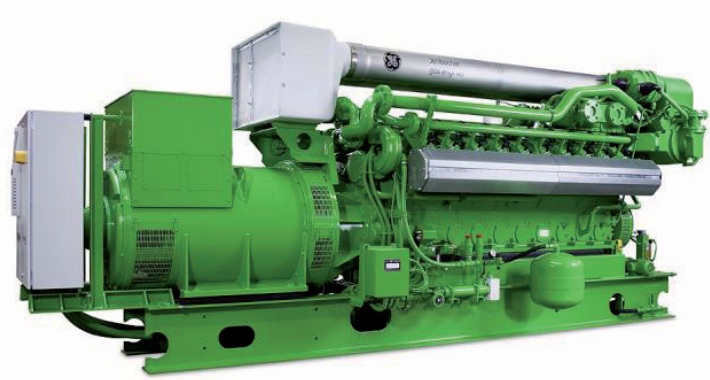

Fig. 5: Gas engine for power generation.

biogas in the biogas plant (to $1 \mathrm{MW}$ ) can be calculated from the equation:

$$
C_{P O M}=\frac{\left(m_{1} \cdot k_{1}\right)+\left(m_{2} \cdot k_{2}\right)+\left(m_{3} \cdot k_{3}\right)+\left(m_{4} \cdot k_{4}\right)}{\left(m_{1}+m_{2}+m_{3}+m_{4}\right)}
$$

where: $m_{1}, m_{2}, m_{3}, m_{4}$ - quantities of the various ingredients (t), k1, k2, k3, k4 - percentages (\%), by weight of methane in the biogas produced from different kinds of raw materials.

Methane content in the biogas:

$$
\begin{array}{ll}
\text { - corn silage } & k_{1}=53 \%, \\
\text { - grass silage } & k_{2}=54 \%, \\
\text { - suds } & k_{3}=60 \%, \\
\text { - manure } & k_{4}=60 \% .
\end{array}
$$

When sizing a biogas plant is paramount, what kind of substrate and how much will be processed. Produced quantity and type of raw materials in the biogas plant per year: 


$$
C_{P O M}=\frac{(3000.53)+(975.54)+(1196.60)+(5200.60)}{(3000+975+1196+5200)}=57,41 \%
$$

Table 5: Kinds of raw materials per year.

\begin{tabular}{|l|l|l|}
\hline Raw material & $\mathbf{m}(\mathbf{t})$ & 6500 \\
\hline Manure & 5200 & 1172 \\
\hline Suds & 1196 & 4000 \\
\hline Corn silage & 3000 & 1300 \\
\hline Grass silage & 975 & 12972 \\
\hline Total & 10371 & \\
\hline
\end{tabular}

Energy produced from $1 \mathrm{~m}^{3}$ of biogas is for $100 \%$ methane $10 \mathrm{kWh}$. For $57,41 \%$ methane it will be:

$$
W_{1}=\frac{57,41}{100} \cdot 10=5,74 \mathrm{kWh} / \mathrm{m}^{3}
$$

From $1 \mathrm{~m}^{3}$ of biogas can be produced 5,74 kWh.

The total amount of energy per year:

$$
W_{\mathrm{TAB}}=V_{\mathrm{B}} \cdot W 1 \quad(k W h)
$$

where: $\mathrm{V}_{\mathrm{B}}$ - total amount of biogas $\left(\mathrm{m}^{3}\right), \mathrm{W}_{1}$ - energy generated from $1 \mathrm{~m} 3$ of biogas $\left(\mathrm{kWh} / \mathrm{m}^{3}\right)$.

$$
W_{\mathrm{TAB}}=937597 \cdot 5,74=5381806,8 \quad k W h(16)
$$

Tank size for digested substrate has to be designed so that it can be digested substrate is stored on at least 5-7 months because farmland belonging to vulnerable areas to the protection of water resources.

Amount of substrate digested for 1 month:

$$
V_{M V S_{1}}=\frac{V_{R M} \cdot D_{g}}{12}\left(m^{3}\right)
$$

where: $\mathrm{V}_{\mathrm{RM}}$ - raw material volume per year $\left(\mathrm{m}^{3}\right), \mathrm{D}_{\mathrm{g}}$ - amount of raw material's degrability (-), usually $\mathrm{Dg}=0.8,12-$ the number of months $(-)$.

$$
V_{M V S_{1}}=\frac{12972.0,8}{12}=864,8 \quad\left(\mathrm{~m}^{3}\right)
$$

Digested substrate should be stored for 6 months. Then the total amount of stored substrate:

$$
V_{M V S_{6}}=864,8 \cdot 6=5188,8 \quad\left(\mathrm{~m}^{3}\right)
$$

Tank parameters:

\section{- diameter $\quad d=30 \mathrm{~m}$, \\ - height $h=8 \mathrm{~m}$.}

The total volume of the tank:

$$
V_{T}=\frac{\pi \cdot d^{2}}{4} \cdot h=\frac{\pi \cdot 30^{2}}{4} \cdot 8=5654,8 \quad\left(m^{3}\right)(20)
$$

Fermenter volume is determined from the relationship:

$V_{F}=V_{D P S} \cdot \tau_{M C T} \quad\left(m^{3}\right)$

where: $\mathrm{V}_{\text {DPS }}$ - daily substrate production ( $\mathrm{m}^{3} /$ day), $\tau_{\text {MCT }}$ - mean contact time (days), from 50 to 80 days.

Daily production of substrate:

$V_{D P S}=\frac{V_{R M}}{12.30} \quad\left(m^{3} / d a y\right)$

where: 30 - average number of days in the month (days).

$V_{D P S}=\frac{12972}{12.30}=36,03 \quad\left(\mathrm{~m}^{3} /\right.$ day $)$

The mean contact time in the fermenter is from 50 to 80 days. Corn silage contains chunks of corn, therefore, the minimum contact time fermenter shall be 60 days.

Then the volume of the fermenter:

$$
V_{F}=36,03.60=2161,8 \mathrm{~m}^{3}
$$

\section{Conclusion}

Bio fuels in Slovakia have great potential. Mainly in agricultural and communal area as it is shown in Figure 2. Agricultural area is specific because we have big areas where are nothing growing, we have places for more and more collective farms where in first place food could be produced and as a additional product can be production of electricity and heat maybe mainly for there own needs. But if they will cover their own need this means that they will not by natural gas or electricity or oil and this will help to our resources of fossil fuels. 


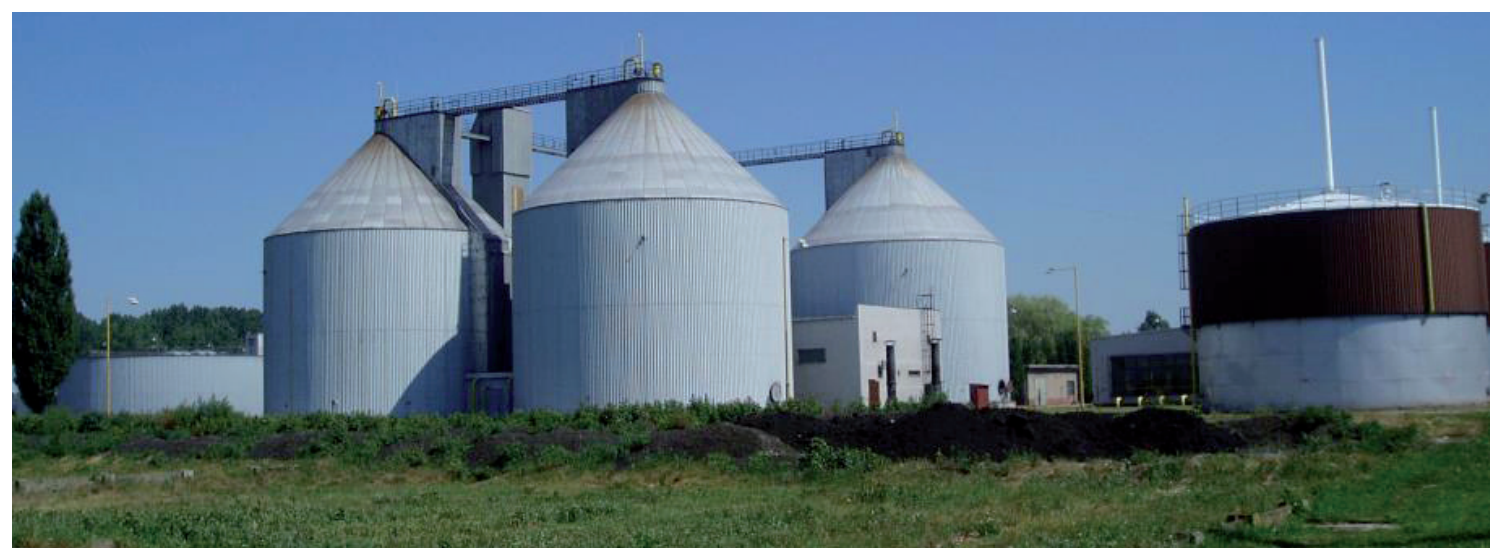

Fig. 6: Dispozition of biogas tanks in sewage treatment plant.

There is also big potential in forest biomass but because we have large areas protected by law, there is no chance to utilize wood or waste from this part of our country. Communal area and sewage plant are very important because people produce more and more waste every year. From this waste we can also produce biogas which can be utilized in co-generation unit for producing electricity and heat which can be used in district heating.

\section{Acknowledgments}

The authors would like to express their gratitude to Scientific Grant Agency VEGA MŠ SR for the support of this work under project no. 1/0686/13 and project KEGA no. 041TUKE-4/2013.

\section{References}

[1] MacKay, D.: Sustainable energy - without the hot air. UIT Cambridge Ltd., 2009, p.368.

[2] Horbaj, P,; Víglaský, J.; Andrejčák, l.: Využitie bioplynu. ES TU Zvolen, 2008. s. 157, ISBN 978-80-228-1857-5.

[3] Rybár, P.; Rybár, R.; Tauš, P.: Alternatívne zdroje energie. TU FBERG Košice, 2001, s.121.

[4] Vranayová, Z.; Vranay, F.; Očipová, D.: Renewable energy for smart buildings in conditions of the Slovak republic, In Journal of international scientific publication. Vol. 3, no.1, 2009, p. 486-493. ISSN 1313-2539.

[5] Oravec, M.; Števo, S.; Sekaj, I.: Comparison of using simple genetic algorithm and parallel genetic algorithm in heat transfer model optimization. J. Cyber. Inform., 9, 2010, p. 13-18.

[6] Jandačka, J.; Malcho, M.; Mikulík, M.: Biomasa ako zdroj energie. ES TU v Žiline, 2006, s.240.

[7] Košičanová, D.; Kapalo, P.: A consumer model for researching the integrative effectiveness of renewable energy sources a design concept of technical equipment. In: Czasopismo Techniczne. Vol. 109, no. 3, 2012, s. 247-253. ISSN 0011-4561

[8] Tkáč, M.; Hvizdoš, S.: Distributed generation and renewable energy sources for sustainable life. In: Distributed Power Generation Systems. Plzeň, 2005, p. 47-52. ISBN 807043371X.

[9] Trebuňa, P.; Kliment, J.; Halčínová, M.; Fil'o, J; Markovič.: Comparison of agglomerative clustering procedures. 978-8087539-54-5 Plzeň, SmartMotion, 2013, p. 185-189.

[10] Trebuňa, F.; Šimčák, F.; Bocko, J.; Trebuňa, P.: Failure analysis of mechanical elements in steelworks equipment by methods of experimental mechanics. Eng. Fail. Anal., 17 (4), 2010, p. 787-801.

[11] Badida, M.; Lumnitzer, E.; Bilová, E.; Filo, M.: The uncertainties of environments parameters measurements as tools of the measurements quality improvement. Univerzitet u Kragujevcu, Kragujevac, 2008, p. 1-5.

[12] Puškár, M.; Bigoš, P.; Puškárová, P.: Accurate measurements of output characteristics and detonations of motorbike high-speed racing engine and their optimization at actual atmospheric conditions and combusted mixture composition. Measurement, 45 (5), 2012, p. 1067-1076.

[13] Lázár, M.; Brestovič,T; Schvarzbacherová, E.: Designing low gas flow meters based on the calometric principle of flow rate measuring. In: The Holistic Approach to Environment. Vol. 1, no. 4, 2011, p. 153-162. ISSN 1848-0071.

[14] Marasová, D. et.al.: Analysis model for determination of contact loads between tube-shaped conveyor belt of a pipe conveyor and carrier rolls. In: Cuprum : Czasopismo naukowo-techniczne górnictwa rud. no. 3, 2010, p. 71-76. ISSN 0137-2815.

[15] Martinka, J.; Kačíková, D.; Hroncová, E.; Ladomerský, J.: Experimental determination of the effect of temperature and oxygen concentration on the production of birch wood main fire emmisions. Journal of Thermal Analysis and Calorimetry. Vol. 110, No.1, p. 485-487, 2012. ISSN 1388-6150. 